\title{
Pirate Nests and the Rise of the British Empire, 1570-1740 by Mark G. Hanna
}

John Donoghue

Loyola University Chicago, jdonoghue@luc.edu

Follow this and additional works at: https://ecommons.luc.edu/history_facpubs

Part of the History Commons

\section{Author Manuscript}

This is a pre-publication author manuscript of the final, published article.

\section{Recommended Citation}

Donoghue, John. Pirate Nests and the Rise of the British Empire, 1570-1740 by Mark G. Hanna. The English Historical Review, 132, 559: 1597-1599, 2017. Retrieved from Loyola eCommons, History: Faculty Publications and Other Works, http://dx.doi.org/10.1093/ehr/cex311

This Book Review is brought to you for free and open access by the Faculty Publications and Other Works by Department at Loyola eCommons. It has been accepted for inclusion in History: Faculty Publications and Other Works by an authorized administrator of Loyola eCommons. For more information, please contact ecommons@luc.edu.

\section{(c) (†) $\ominus$}

This work is licensed under a Creative Commons Attribution-Noncommercial-No Derivative Works 3.0 License. (c) Oxford University Press 2017 
Mark G. Hanna, Pirates Nests and the Rise of the British Empire, 1570-1740 (Chapel Hill: University of North Carolina Press, 2015)

Mark Hanna's important book makes two very valuable contributions to the history of the British Atlantic. First, it recovers piracy's vital part in colonial economic growth during the seventeenth century. Secondly, it explains piracy's ultimate demise in the early eighteenth century by tracing the regulatory revolution that turned an assemblage of wayward Atlantic colonies into a profitable commercial empire.

Hanna begins the book in the English West Country, starting with the Elizabethan Sea Dogs and their war to force open Spanish America for English commerce. He then moves on from Crown efforts to suppress local support for these pirates to the piratical ventures that puritan revolutionaries organized a generation later, all to spur on early English colonization. Robert Rich, the Second Ear of Warwick looms large here, and while other historians have recognized his importance, Hanna finally gives him his proper due as the indispensable figure of early English expansion. Hanna turns next to Jamaica's transformation from a consolation prize in Cromwell's 1655 Western Design to a lucrative pirates nest via the exploits of privateers, especially those of Captain Henry Morgan. Privateering thrived due to the financial and political support it received from Jamaican merchants, a faction of planters, and Governor Thomas Modyford. Hanna also shows how the state, the Royal African Company, and a new faction of Jamaican elites eventually refashioned Jamaica from a colony based on plunder to one based on plantation slavery and the slave trade, a pattern that would be repeated in South Carolina.

Reaching the 1680s, Hanna follows privateers from the South Seas to the eastern seaboard of North America. There they found fencers and markets for spoils acquired on raids in the Red Sea and Indian Ocean. They also found legal refuge under lenient proprietary and charter regimes in Bermuda, South Carolina, Pennsylvania, East and West Jersey, Massachusetts, and Rhode Island. A few of these pirates, unlike most of their predecessors in Jamaica, opted to settle and integrate into these cash-strapped and (in the case of South Carolina) labor-starved colonial communities that welcomed their pilfered bullion, slaves, jewels, and calico textiles. Even the royal colony of New York proved receptive, although Virginia remained largely hostile. Hanna rightly insists that legal cover remained paramount for pirates until the black flag era, a theme he explores to great effect in the case of the Red Sea raiders, who carried commissions tendered by colonial governments during the Nine Years War. When these voyages, led principally by Henry Every and Thomas Tew, returned with booty robbed from Muslims in the East Indies, they were justified by colonists as revenge for the enslavement of Englishmen by pirates sailing out of Tunis and Algiers. While it is well-known that the English at home and abroad drew upon the Black Legend to justify pillaging the Spanish Empire (ca. 1560-1670), Hanna introduces new evidence that colonists devised an Islamic Black Legend to justify East Indian piracy.

One of the major themes running throughout the book is that piracy, while a boon for most colonies, was a double-edged sword for the state. While piracy provided the bullion, goods, and slaves that made colonies work economically, they also stole market shares from monopolies such as the East India Company and the Royal African Company. Piracy also disrupted international relations, hindered commercial expansion in foreign markets, most importantly the slave trade to Spanish America, and proved difficult to prosecute due to legal loopholes and piracy's entrenched position in local economies. Local traditions of liberty, ranging from the 
West Country to Jamaica to Rhode Island, proved resilient in the face of perceived jurisdictional intrusions by the state.

In Chapters 6-8, Hanna is at his best, explaining how the imperial state expanded its sovereign dominion over the colonies to suppress piracy and encourage commercial expansion. In the wake of the Glorious Revolution and the Treaty of Ryswick (1696), Parliament, ultimately in concert with colonial planters, merchants, and government leaders, shifted commercial policy to encourage colonial traffic with England and free trade in the markets formerly monopolized by the East India Company and the Royal African Company. The volume and profitability of colonial trade exploded, bolstered by the slave-trading asiento the British won as a concession following the War of Spanish Succession. Pirates nests flourished in markets limited by monopolies and mercantile restrictions; when these were removed, colonies found piracy, particularly in regard to the slave trade, a detriment rather than an asset. They also faced the wrath of new Crown-regulated, colonial vice-admiralty courts, which provided the state, at long last, with the power to effectually suppress piracy.

The book has garnered a slew of rewards and has been appreciated, deservedly-so, as an original, exhaustively-researched contribution to imperial history. Early American scholars, however, will question whether Hanna overstates the communal cohesion behind piracy's colonial success. For instance, he attributes Pennsylvania's resistance to anti-piracy initiatives to the unity of the Quaker community there; but the period under discussion overlapped with the Keithian Schism, which stemmed in part from condemnations of slave trading, the very business that helped keep Quakers wealthy and pirates in their employ.

While Hanna's approach is innovative, many historians of piracy will take issue with his almost exclusive, top-down perspective. His view from above reduces the history of piracy to a history of commerce. While Hanna proves this to be one vital facet in the history of early modern Atlantic piracy, the top-down view marginalizes the vital, bottom-up history that helps us understand why many "went on the account" in the first place. As a result, his treatment of the age of the buccaneers (ca. 1655-1688) and black flag pirates (1716-1726) fails to persuade this writer. In both epochs, pirates became so often to evade or escape unfree and often forced labor in brutal conditions on plantations and in the imperial military. As a range of contemporary sources reveal, they organized piratical societies along politically and socially egalitarian lines that operated internally, in terms of the distribution and consumption of wealth, in accord with decidedly anti-capitalist principles. His discussion of buccaneering is so brief that it fails to merit inclusion in the index. In the case of the black flag pirates, Hanna largely abandons his impressive archival research in favor of literary analysis, which he enlists in an unconvincing effort to disprove that workers could instrumentalize piracy to resist labor exploitation.

Hanna's engaging book has opened up a rich new chapter in the history of piracy through its emphasis on trade. His excellent contribution will do much to supplement social, labor, and political histories of piracy from below. 